Original Research

\title{
Determining Indigenous Microalgae Species in Malakand Water Bodies for Potential Use as a Biofuel Production Source
}

\author{
Fida Hussain 1,2,3*, Bei Lu, Xin Lan, Jing Lyu ${ }^{5,6}$, Hongkai Huang ${ }^{4}$, Wenguang Zhou', \\ Syed Zahir Shah ${ }^{3}$, Muzammil Shah ${ }^{3,7}$, Faisal Raza ${ }^{8}$, Muhammad Saeed ${ }^{2}$, \\ Muhammad Shuaib ${ }^{9}$
}

${ }^{1}$ School of Resources, Environmental \& Chemical Engineering and Key Laboratory of Poyang Lake Environment and Resource Utilization, Nanchang University, Nanchang, 330000, China.

${ }^{2}$ Department of Botany, Qurtuba University of Science and Information Technology, Peshawar 25100, KPK, Pakistan.

${ }^{3}$ Department of Botany, Islamia College Peshawar, 25100, Pakistan.

${ }^{4}$ The Fu Foundation School of Engineering and Applied Science, Columbia University in the City of New York, New York, NY 10027, United States of America.

${ }^{5}$ Key Laboratory of Marine Geology and Environment, Institute of Oceanology, Chinese Academy of Sciences, Qingdao, China.

${ }^{6}$ College of Earth Sciences, University of Chinese Academy of Sciences, Beijing, China. ${ }^{7}$ Department of Biological Sciences King Abdulaziz University, Jeddah 21589, Saudi Arabia.

${ }^{8}$ China Pharmaceutical University, Nanjing China.

${ }^{9}$ School of Ecology and Environmental Science, Yunnan University, North Cuihu road, Kunming, Yunnan, 650091, PR-China.

Received: 2 August 2017

Accepted: 30 January 2018

\begin{abstract}
As a renewable energy source, microalgae have wide interest as a potential tool to produce biofuel and bioproducts. Prevailing in the local habitat, indigenous microalgae are more successful for wastewater treatment processes. Integrated microalgae-based biofuel and bioproduct production with wastewater treatment is a successful practice of modern research. This report describes the isolation and identification of 61 microalgal strains from lakes, springs, ponds, creeks, and rivers of the gigantic area of Malakand, Pakistan. Our study involves the seasonal existence of Chlorophyta in the area, with most dominant flora identified in the summer season followed by spring, autumn, and winter seasons, respectively. The highest ratio of microalgae was found in stagnant waters followed by slow-running water and running water, respectively. However, algal species were reported from all water bodies throughout the year. Commercially important genera like Chlorella, Scenedesmus, and Chlamydomonas were also reported,
\end{abstract}

*e-mail: fidaicp@gmail.com

Note: The first two authors are equal contributing authors 
attracting the research area for further analysis regarding biofuel, bioproduct production, and simultaneous wastewater treatment.

Keywords: biofuel, bioproducts, Chlorophyta, Malakand wastewater treatment, conservation

\section{Introduction}

Growing concerns regarding renewable energy and wastewater treatment have earned much attention in modern science. Among biological sources, microalgae are more successful for their high growth rate, high photosynthetic efficiency, and high nutrient uptake with their cultivation ability on non-arable land. Microalgae have the ability to produce biofuel, bioproducts, and bio fertilizers with simultaneous wastewater treatment [16]. Compared to other wastewater treatment processes like physical and chemical, microalgae-based treatment is more economic and viable for its dual ability of bioproduct production as well. They can use wastewater as their growth nutrients and can produce biofuel and bioproducts [7-9].

Microalgae are environmentally friendly for their high photosynthetic efficiency, resulting in biomass production, $\mathrm{CO}_{2}$ capture, and oxygen release. The potential of microalgae for $\mathrm{CO}_{2}$ sequestration is tremendously high, and most microalgal strains can tolerate up to $20 \% \mathrm{CO}_{2}$ concentration in air, contributing to a reduction in greenhouse gases and global warming $[10,11]$.

The major pollutants in many kinds of wastewaters are ammonia and phosphorus, which cause eutrophication, odors, deaths of aquatic animals, and generally making it unfit for human use [12-14]. Microalgae is a good tool for uptaking these nutrients as a source of their growth substance fixing it to valuable products [15-18]. The efficiency for uptaking these nutrients by different microalgal strains is $100 \%$, providing the best solution for the wastewater treatment through biological means [19-23].

Adjusted to local habitats, indigenous microalgae has more advantages over commercially available strains. They can tolerate high stress conditions like high ammonia, phosphorus, temperatures, and $\mathrm{pH}$ variations compared to the commercial strains. So it is more imperative to study the local strains for its

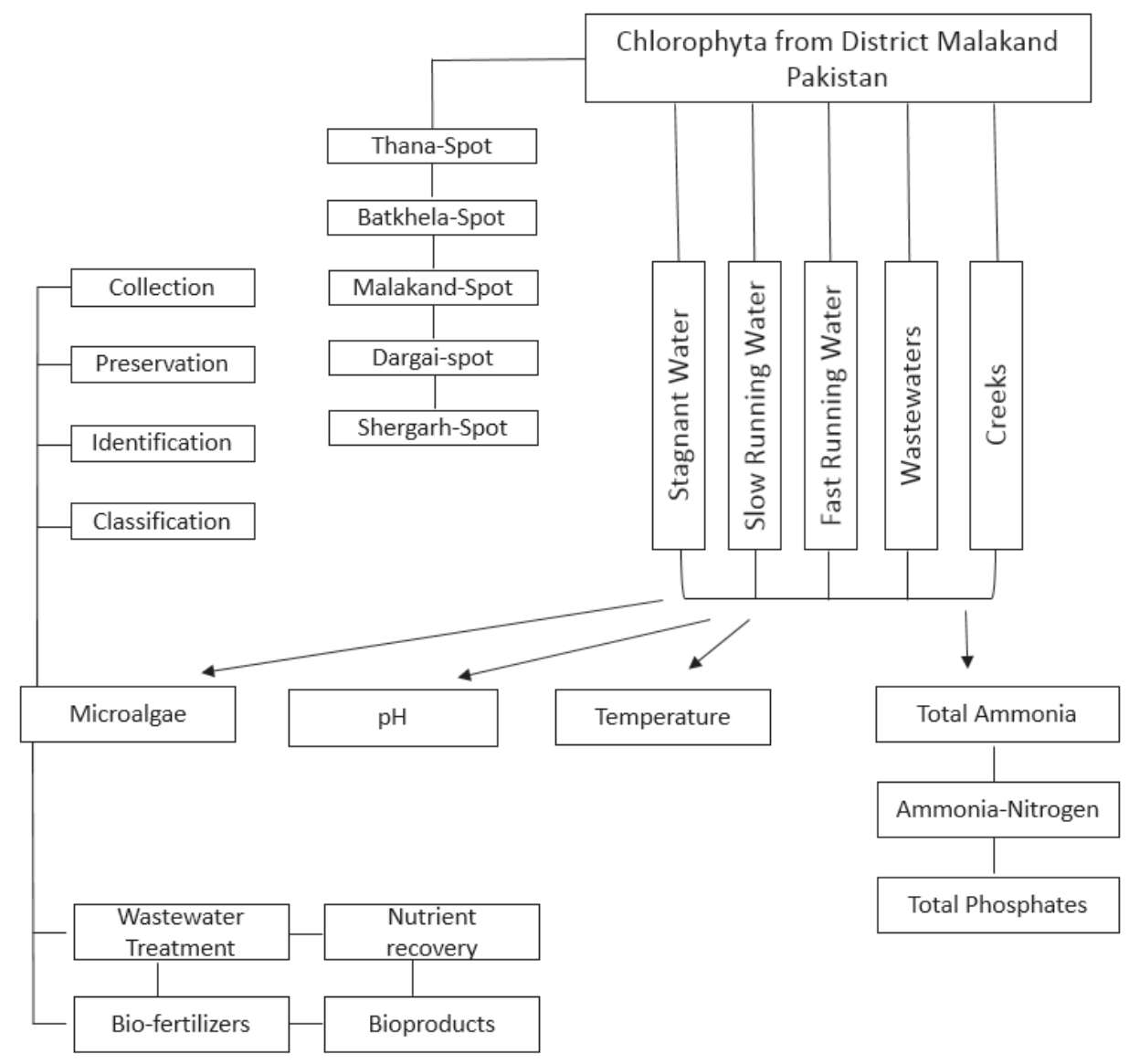

Fig. 1. Schematic details representing the entire work plan from microalgal collection to biofuel production. 
potential [24-27]. The present study is part of ongoing efforts (Fig. 1) to study the efficient microalgal strains isolated from Malakand district for their biofuel production and wastewater treatment. Focusing on microalgae-based processes, the unexplored area of Malakand is awaiting the opportunity to play its role in algae research and to contribute to the economy of the world in general.

\section{Materials and Methods}

\section{Microalgal Strains Collection}

To investigate microalgal strains and the various growth parameters, i.e., $\mathrm{pH}$, temperature, total phosphorus, and ammonia-nitrogen in the research area, various sites were selected from Malakand Valley on the basis of adequate water bodies present. These sampling sites were based on the type of water (i.e., stagnant/ running), the number of water bodies, profundity of water bodies, seasonality, contamination, and turbidity. The main sites selected for current work were the Thana, Batkhela, Malakand, Dargai, and Shergarh areas of Malakand Valley. Sample collection was done from various water bodies of these five major areas.

Regular monthly algal samplings were made from January to December using planktonic nets, hand picking, scratching of various materials in water, and taking water in bottles from the surface and at a depth of 2-3 m below for the study of physico-chemical characteristics of water and identification of phytoplankton (Chlorophyta). The specimens were collected in polythene bags and taken to a laboratory. To prevent any decay and decomposition, the samples were preserved in $10 \%$ formalin. Duplicate samples were also collected from each sampling spot at 10:00 and 14:00, with a phytoplankton net of mesh size for the microalgae and estimation of different growth factors like $\mathrm{pH}$, temperature, ammonia, and total phosphorus.

\section{Analytical Methods}

The following procedures were used to determine the physical and chemical parameters of the water. The $\mathrm{pH}$ of the water was determined at the time of collection by using a $\mathrm{pH}$ meter. The readings were further verified at PCSIR laboratories Peshawar. For determining $\mathrm{pH}$ (method No. 8156) the pH-meter was standardized with basic, neutral, and alkaline solutions and then subjected to determine the $\mathrm{pH}$ of the samples; the samples were diluted several time depending on their nature. Similarly, the turbidity of water was noted with the help of a turbidometer (method No. TU 5400) on the spot during collection at all the sites. Ammonia nitrogen $\left(\mathrm{NH}_{4}-\mathrm{N}\right)$ and total phosphorus (TP) of water were determined using a Hach DR 5000 Spectrophotometer Manual (Hach, 2008). The method numbers for $\mathrm{NH}_{4}-\mathrm{N}$ and TP used were Hach 10031 and 10127, respectively.
The temperatures of the air and water were determined during collection. A thermometer (Steve Spangler, method No. 30023) was used for temperature measurement; air temperature was measured at about 1-2 $\mathrm{m}$ above the water surface. To rule out the effect of depth of water bodies, the temperature of water was recorded at two different positions in water, i.e., surface and deep in water, and their mean value was taken as the temperature of that habitat. Similarly, to avoid influence of the time of the day, temperatures were recorded twice a day, i.e., before and after collection at 09:00 and 13:00, respectively. Mean values for temperature taken were used to analyze its effect on the algal communities.

\section{Microalgal Identification}

Algal samples were carried to the Pakistan Museum of Natural History Islamabad (PMNH). A total of $0.5 \mathrm{ml}$ samples were pipetted and mounted on slides. The slides were then heated with a spirit lamp to avoid any traces of moisture and stick the algal specimens to the slides. The slides were then provided with clove oil to enhance the image of the microscopes. Determining cell sizes was done using the ocular and stage micrometers. Slides were observed at a magnification of $40 \mathrm{X}$ and $100 \mathrm{X}$ of an inverted electric microscope (BH-2 Olympus, Japan). The Photomicrographs were taken with a Letiz Wetzlar camera and identified with the available literature $[11,28]$

\section{Results and Discussion}

\section{Local Isolation and Identification of Microalgal Species}

The algae collected from different areas were identified on the basis of their morphology, pigmentation, cell, and chloroplast nature using available literature (Prescott, 1951) and [29]. The main objective of the current work was to record the indigenous green algae, which are more common in almost all freshwater habitats and a main tool in current research like $\mathrm{CO}_{2}$ biomitigation and biofuel production [30-35].

\section{Chlorophyta}

There were 61 species of green algae recorded from 5 major areas of the valley. The genera recorded are: Ankistrodesmus (2 sp), Asterococcus (1 sp), Basicladia (1 sp), Bulbocphaete (1 sp), Characium (3 sp), Chaetophora (1 sp), Chlamydomonas (2 ), Chlorella (2 sp), Cladospora (1sp), Closterium (4sp), Coelastrum (2 sp), Coleochaete (1 sp), Cosmarium (3 sp), Crucignea (2 sp), Geminella (1 $\mathrm{sp})$, Gloeocystis (2 sp), Gonium (1 sp), Haematococcus (1sp), Hydrodictyon (1 sp), Mougeotia (2 sp), Oedogonium (1 sp), Oocystis (3 sp), Pandorina (1 sp), Pediastrum 
Table 1. Microalgal collection sites established in the current study.

\begin{tabular}{|c|c|c|c|}
\hline Species & Collection sites & Collection water bodies & Season \\
\hline Ankistrodesmus & The west Gunyar road, Thana & Pond & Summer and early spring \\
\hline Asterococcus & Near the cricket ground, Dhanda, Thana & Municipal wastewater & All Seasons \\
\hline Basicladia & Near the road bank, Dargai & Freshwater lake & Summer \\
\hline Bulbochaete & Shago naka Shergarh & Pond & winter \\
\hline Characium & Malakand & Mountain spring & All Seasons \\
\hline Chaetophora & Malakand & Mountain spring & Summer \\
\hline Chlamydomonas & Alladhanddheri, Thana & Municipal wastewater & Summer \\
\hline Chlorella & Batkhela and Shergarh & Municipal waste/ freshwater lake & All seasons \\
\hline Cladophora & Malakand & Spring & Summer \\
\hline Closterium & Near head work, Batkhela & Main river swat & Summer \\
\hline Coelastrum & Dargai, Shergarh and Thana & Stagnant water bodies & Summer \\
\hline Coleochaete & The west Gunyar road, Thana & Pond & Spring and Summer \\
\hline Cosmarium & Alladhanddheri, Thana & Municipal wastewater & All seasons \\
\hline Crucigenia & Shergarh & Municipal wastewater & Summer and Autumn \\
\hline Geminella & Dargai, Shergarh & Stagnant water bodies & Summer \\
\hline Gloeocystis & Malakand & Mountain spring of & Summer \\
\hline Gonium & Near the road bank and Dargai & Freshwater lake & Summer \\
\hline Haematococcus & Batkhela & Municipal waste / freshwater lake & Summer \\
\hline Hydrodictyon & Near the cricket ground, Batkhela & Stagnant water & Summer \\
\hline Mougeotia & Near the cricket ground, Batkhela & Stagnant water & Winter and Spring \\
\hline Oedogonium & Malakand & Mountain spring & Winter and Spring \\
\hline Oocystis & Alladhanddheri, Thana & Municipal wastewater & All Seasons \\
\hline Pandorina & The west Gunyar road, Thana & Pond & All Seasons \\
\hline Pediastrum & Dargai and Thana & Stagnant water bodies & All Seasons \\
\hline Scenedesmus & Dargai and Thana & Stagnant water bodies, & All Seasons \\
\hline Sphaeroplea & Batkhela & Municipal waste/ freshwater lake, & Summer \\
\hline Tetraedron & Thana Alladhanddheri & Municipal wastewater & Summer \\
\hline Tetrospora & Totakan, Batkhela & Municipal wastewater & Summer \\
\hline Ulothrix & Alladhanddheri, Thana & Municipal wastewater & All Seasons \\
\hline
\end{tabular}

(2 sp), Pithopora (1 sp), pleodorina (1 sp), Scenedesmus (4 sp), Sphaeroplea (1 sp), Tetraedron (6 sp), Tetrospora (2 sp), Ulothrix (2 sp), Volvox (2 sp), and Westella (1 sp) (Table 1). Following are details of the species identified. Members of Chlorophyta are the main biological tool in our current research $[2,8,10,11,36-40]$.

\section{Species Distribution}

Species of Ankistrodesmus were observed in collection from the regions of Thana, Batkhela, and Shergarh. The members of the species were common for all habitats except for the wastewater bodies. A single species, A. falacatus, was observed by [41] from Dandot, Pakistan. Similarly, five species of Ankistrodesmus were observed from Haripur Valley by [42].

Asterococcus, a genus with single species $A$. limneticus, was recorded from Batkhela and Dargai regions of the present research area. The species was common in summer and early winter, showing that the presence of the species was reduced with cold. The species was common in stagnant water and small streams of the explored areas. Some of the previous results suggest the existence of Asterococcus in the same habitat. The same genus was recorded in the work of Chughtai et al. [43] from D.G. Khan, Pakistan. The same species was also 
reported by Ali et al. [44] from Swat Valley - a similar habitat to the present research area.

The genus Basicladia observed in the present research work was represented by a single species only, i.e., B. chelomum. The species was common to running water and was found among algal blooms. From the present collection the species was observed in three areas: Thana, Malakand, and Shergarh. Summer season was found to be most favorable for their existence in said habitats. Members of this genus were reported by Sher and Hazrat [45] from the Swat River, which passes through the present research area and is one of the largest habitats.

A single species of Bulbochaete was found from different spots of the research areas (Table 1). Bulbochaete was very common in the summer season but not in the winter. Members of the genus were recorded by Sarim et al. [46] from Peshawar Valley. Similarly, [47] observed some members of the said genus from the freshwater bodies of Gujranwalla, Pakistan.

Characium, a very common genus of freshwater Chlorophyta, was identified with three species from all habitats in all parts of the valley. The members of the genus were recorded in all seasons irrespective of the effects of temperature. Many previous records have been established for Characium. Four species of Characium were identified by [48] from Sindh, Pakistan. Similarly, 2 species of the same genus were identified by Korai et al. [49] from Thatta Valley, Sindh.

Chaetophora, a commonly occurring genus of green algae, was represented by a single species in the present research work. It was found in the collection from Batkhela and Malakand regions of the valley. Summer season mostly favored the presence of Chaetophora in the present research areas, although it was also found in other seasons of the year. The species was observed in the bank of the Swat River and some slow-running streams in the research areas. Similar work has been shown by other researchers. [50] also observed three species of Chaetophora from slow-running lakes and rivers in Sindh, Pakistan.

Chlamydomonas was represented by two species - C. globosa and C. pseudopertyi - from different regions of the research area. The species were common to almost all habitats and seasons. They were commonly found in stagnant, running, and waste water. The members were very common in summer season but decline starting with the arrival of the cold season. 5 species of Chalamydomonas were observed in our previous study from Peshawar Valley [51]. This shows the frequent occurrence of the Chlamydomonas from similar habitat.

Chlorella, the most important genus for other studies like $\mathrm{CO}_{2}$ biomitigation, biofuel production, and source of food [13], was also an inhabitant of the different areas of the present work. It was represented by two species, C. ellipsoidea and C. vulgaris, that were reported in all seasons and most of the habitats. In previous studies, species of Chlorella were identified from different parts of the country. [52] observed the species C. pyrinoidosa from Haleji Lake, Sindh. Some species of Chlorella were also reported by Shahnaz et al. [53] from paddy fields in Lahore, Pakistan.

Closterium, with four different species, was reported from different parts of the research area and was found to be present in all types of habitats, including wastewater bodies. Four species were reported in this study. They were most common in summer, although they existed in other seasons as well. A large variety of species (10 $\mathrm{sp}$ ) were reported in our previous results from Peshawar valley [51]. 24 species of Closterium were reported by [54] from different parts of the country.

Coelastrum was reported in three regions of the valley: Thana, Malakand, and Shergarh. The species were common in stagnant water and were also observed in the wastewater bodies. The favorable season for their growth was found to be summer. A single species of Coelastrum was also identified from freshwater bodies of Haripur Valley, Pakistan, by [55]. The genus Coleochaete was represented by only one species from the present work: C. orbicularis. The species was found in three regions of the valley (Table 2). It was common in the spring season and was continuously growing throughout the summer and reduced at the arrival of winter. Stagnant water favors growth as compared to other water bodies. Similar results were found by Ali et al. [44] in their collection from Swat, Pakistan. The similarity is due to the similar living habitat of the two regions.

The other commonly occurring genus found was Cosmarium, which was represented by 3 species in the present work. The species were recorded in all major spots except Malakand. Both the cold and hot seasons favor the growth of these species. They were found in stagnant, slow-running, and fast-running water bodies of the valley. Ten species of Cosmarium were identified by different water habitats ranging from stagnant to running water of northeastern Pakistan.

The genus Crucignea was reported to be represented by two species in the present work. The two species were only restricted to the upper region of the valley, which are relatively cold, i.e., Thana, Batkhela, and Malakand. The species were present in spring, summer, and autumn seasons and were not reported in winter. Stagnant and slow-running waters were more suitable for their growth. Crucignea genus was reported in the work of [56] from the Soan River of Punjab Province.

The genus Geminella was reported to have a single species from different parts of the valley. The species $G$. ordinate was most commonly found in stagnant water of the present area during the summer. The species occurrence was also common in winter. A single species G. minor was recorded by Leghari et al. [57] from the Kunhar River, where the temperature remains in the range of $8-27^{\circ} \mathrm{C}$.

Gloeocystis was reported with two species from different parts of the research area. The species were frequent in summer season and the growth was reduced with a decrease in temperature. They were present in all types of habitats, including stagnant, running, and 
waste water bodies. Member of the same genus was also reported by Shah and Faridi [29] from the paddy fields of Mathra Valley, Peshawar. The genus Gonium was represented by a single species and was found only in the Shergarh area of the present work. The species $G$. pacturale was identified during summer collection in a small pond. A single species of Gonium was also recorded by Zarina and Shameel [58] from different parts of Punjab, including Lahore and Kasur.

Haematococcus was identified from a single the area of Thana of the research spot represented by a

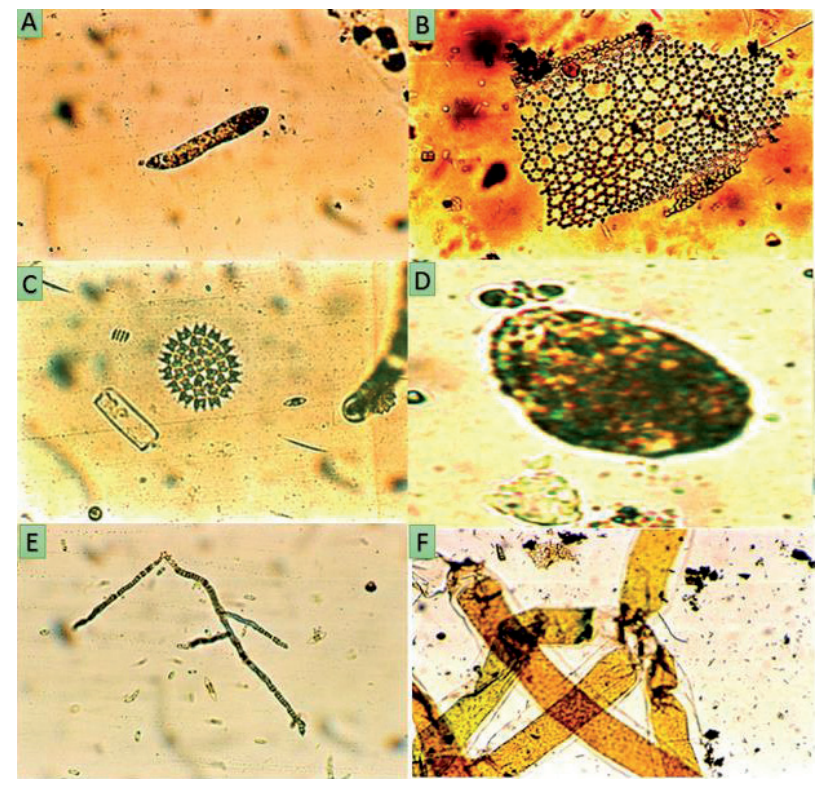

Fig. 2a. Representative genera investigated from Malakand District - A: Characium, B: Hydrodictyon, C: Pediastrum, D: Ankistrodesmus, E: Basicladia, and F: Bulbochaete.

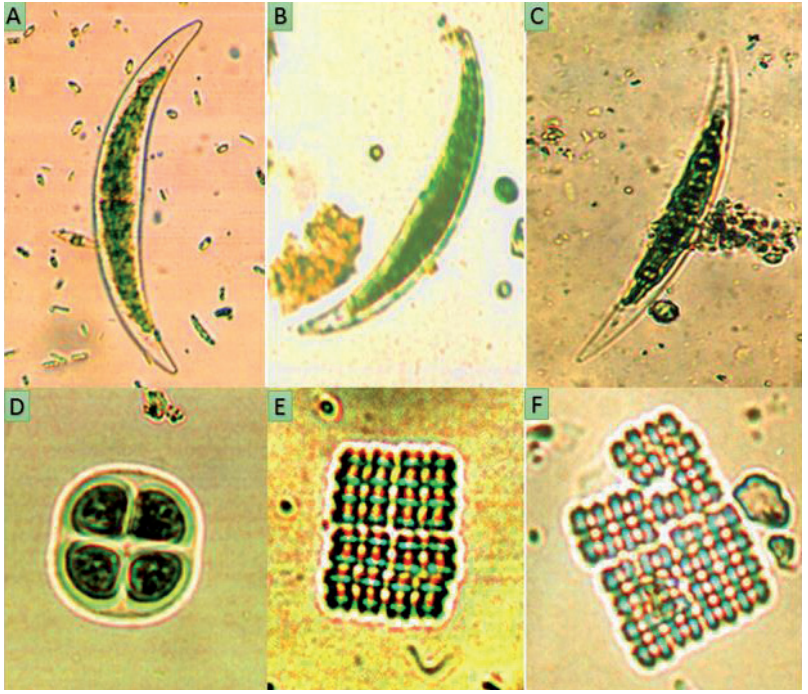

Fig. 2b. Some representative genera/species investigated from Malakand District-A: Closterium leibleinii, B: C. ehrenburghii, C: C. venus, D: Tetraedron, E: Crucigenia apicuclata, and F: $C$. tetrapedia. single species $H$. lacustris. The species was identified from a very small pond that had bloomed slightly. The same species was also identified by Ali et al. [44] from freshwater bodies of Swat, Pakistan. Hydrodictyon was reported from the research spot represented by a single species $H$. reticulatum. It was found in the collection from Batkhela and Dargai regions of the valley. The species was specific to wastewater. This species was also common during summer season but was also found in other seasons. A single species of Hydrodictyon was also reported by [59] from the Naguman region of Peshawar Valley.

Mougeotia with two species was observed from different spots of the research place. It was common in summer and early winter and saw fewer occurrences in late winter. The species were adjusted to stagnant and wastewater bodies sometime in running water. A variety of Mougeotia exists in the country, which was reported by [60] reported members of Mougeotia from different locations of Peshawar Valley. The genus Oedogonium was represented by a single species from two locations of the research area. O. angustissimum was reported from running water and was found in stagnant water. [61] reported two species of Oedogonium from Kurram River, Parachinar.

The genus Oocystis was reported to have three species from different parts of the area. The species were common in all seasons of the year and existed in most of the habitats. No record of Oocystis was obtained from the wastewater bodies of the area. The said genus was observed from the fountain water of Lahore, Pakistan, which was a new record for the said area [62].

Pandorina was represented by single species from the present collection. The species $P$. morum was recovered from different water habitats, including both running and stagnant water of the area. All the seasons were found to be favorable for their growth. [63] recorded the members of the species from polluted water of the Ravi River, Pakistan. Pediastrum was reported with two species from the research spot. These species were found to tolerate all environmental conditions with respect to temperature

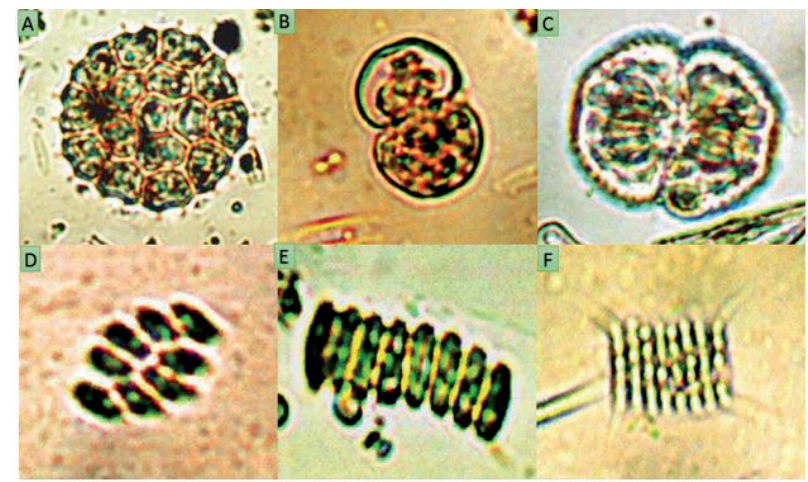

Fig. 2c. Some representative genera/species investigated from Malakand District - A: Asterococcus, B: Cosmarium, C: Cosmarium, D: Scenedesmus obliquus, E: S. armatus, and F: S. serratus. 
and water quality. The previous record shows a variety of the existence of Pediastrum in different habitats in the country. A new species, P. habibII, was reported by [64] from Karachi. Similarly, nine species of Pediastrum were identified by Leghari et al. [48] from Sindh.

Scenedesmus was observed to have four species from different localities in the area. The species were very common to all habitats and were not affected by water quality and seasons of the year. A total of 23 species were recorded by Leghari et al. [48] from different parts of Sindh, Pakistan.

Sphaeroplea observed in the present work was represented by a single species, $S$. annulina. The species was recorded from a single place only: Thana. The favorable season for its existence was observed to be summer, while the favorable habitat was stagnant water. Ali et al. [44] observed a member of the genus Sphaeroplea while studying green algae from freshwater bodies of Swat Valley, Pakistan.

Tetraedron, the most common to the freshwater habitats of the country, was observed with a variety of species. A total of 6 species of Tetraedron were observed from all the studied areas. Sarim and Kouser [42] identified 11 species of Tetraedron from Haripur Valley, Pakistan. Our previous study showed the existence of 10 species of Tetraedron from Peshawar Valley [51, 65].

Two species of Tetraspora were reported from the present collection. These species were present in almost all habitats of the area, particularly in stagnant water. The seasonality of the species was variable, with summer being most favorable. A slight lower temperature resulted in reduced growth of the species. Tetraspora was also reported in previous work from the different parts of the country, e.g., Butt [66] isolated a single species T. gelatinosa from Sindh, Pakistan.

Ulothrix has two species recorded in this study. Both species were common in all seasons of the year. Early winter and summer seasons were found to be most favorable for their existence. The stagnant and slowrunning water were more suitable for their growth. Two species of Ulothrix were observed from the Kurram River, Parachinar by Badshah et al. [61]. Similarly, six species of Ulothrix were reported by Akhtar and Rehman [67] from the Jalala area of Mardan Valley, which is very close to the present research spot of Shergarh. The habitats of both areas are almost similar and favor the growth of such types of algae [68-77].

\section{Effects of Ammonia and Phosphorus on the Microalgal Community}

Ammonia is the most important growth factor for most of the microalgae [20,78-80], where it can heavily effect the distribution of algal communities in specific habitats. High diversity and growth rate of microalgae were recorded in spots like wastewater and stagnant water, containing a high proportion of ammonia. Similarly, the summer season showed much growth in comparison to other seasons. This might be due to the greater dissolution of ammonia contents in the water bodies in summer season [81]. On the other hand, phosphorus played a vital role in the distribution and growth of microalgae in these habitats. Phosphorus is one of the two main growth factors that could promote microalgal growth [82-85]. In the current work the microalgal species like Chlorella, Scenedesmus, and Pandorina were found to be more tolerant to high phosphorus and were present in the water bodies containing high phosphorus, whereas some strains like Chlamydomonas and Gonium were observed to be less tolerant as they were absent in high phosphorus-containing water bodies. These findings are verified by comparison with other researchers [86, 87].

\section{Future Prospects and Goals}

There are a lot of potential strains recorded in the current research. Most important strain reported in our work, Chlorella, is used widely throughout the world for its high-rate wastewater treatment, biofuel production, and other valuable products [14, 88-91]. The strains will be further analyzed for their abilities. Scenedesmus, another important strain, were also common in the hills of Malakand and is also a promising strain for biofuel and wastewater treatment, and is in wide practice in modern research [92-95]. It is concluded from the above work that there is a great variety of algae existing in the water bodies of this area. More intensive and extensive work is required to be conducted on all groups of algae, including blue-green and green algae in the area. The present study revealed that the best growth season for all isolated genera was summer. This may be attributed to favorable water temperature and also to the availability of more nutrients in summer [25, 96-101]. Apart from summer, some of the species were common for all the seasons and some were common in summer with early winter or spring. The freshwater habitats studied were rivers, streams, ponds, stagnant water, and wastewater. Among these, stagnant water/ponds were found to be most favorable for the growth of most of the species. Slow-running water bodies also provided suitable growth habitat. The indigenous freshwater strains are more suitable for use in biofuel technology [102-107].

\section{Conclusions}

Among the total of 56 strains identified from Malakand, Pakistan, three commercially important strains - Chlorella, Chlamydomonas, and Scenedesmus - were also reported, attracting further attention by the researchers. There is a variation in different groups of algae among different seasons and water bodies studied. Because of the high diversity, the summer season provide the best time for algal studies in an open environment. There is a need for further exploration of microalgae for possible wastewater treatment and biofuel production. 


\section{Acknowledgements}

This study was supported by the National Natural Science Foundation of China (Nos. 51668044 and 31571807) and the Higher Education Commission Pakistan under IRSIP scholarship. Scientific help provided by the University of Minnesota, USA, is gratefully acknowledged.

\section{Conflict of Interest}

The authors declare no conflict of interest.

\section{References}

1. CHRISTENSON L., SIMS R. Production and harvesting of microalgae for wastewater treatment, biofuels, and bioproducts. Biotechnol Adv 29, 686, 2011.

2. ZHOU W., MIN M., LI Y., HU B., MA X., et al. A heterophotoautotrophic two-stage cultivation process to improve wastewater nutrient removal and enhance algal lipid accumulation. Bioresour Technol 110, 448, 2012.

3. ABDELAZIZ A.E., LEITE G.B., BELHAJ M.A., HALLENBECK P.C. Screening microalgae native to Quebec for wastewater treatment and biodiesel production. Bioresour Technol 157, 140, 2014.

4. TAN C.H., SHOW P.L., CHANG J.S., LING T.C., LAN J.C. Novel approaches of producing bioenergies from microalgae: A recent review. Biotechnol Adv 33, 1219, 2015.

5. SHUAIB M., ALI K., ZEB U., AHMED S., ALI S., et al. To assess the fresh water algal diversity in relation to water quality from river Panjkora, district Dir lower, Pakistan. Pure and Applied Biology (PAB) 6, 645, 2017.

6. ALCANTARA C., DOMINGUEZ J.M., GARCIA D., BLANCO S., PEREZ R., et al. Evaluation of wastewater treatment in a novel anoxic-aerobic algal-bacterial photobioreactor with biomass recycling through carbon and nitrogen mass balances. Bioresource Technology 191, 173, 2015.

7. SYDNEY E.B., DA SILVA T.E., TOKARSKI A., NOVAK A.C., DE CARVALHO J.C., et al. Screening of microalgae with potential for biodiesel production and nutrient removal from treated domestic sewage. Applied Energy 88, 3291, 2011.

8. ZHOU W., LI Y., MIN M., HU B., ZHANG H., et al. Growing wastewater-born microalga Auxenochlorella protothecoides UMN280 on concentrated municipal wastewater for simultaneous nutrient removal and energy feedstock production. Applied Energy 98, 433, 2012.

9. PARK J.B., CRAGGS R.J., SHILTON A.N. Wastewater treatment high rate algal ponds for biofuel production. Bioresour Technol 102, 35, 2011.

10. HU B., MIN M., ZHOU W., LI Y., MOHR M., et al. Influence of exogenous $\mathrm{CO}_{2}$ on biomass and lipid accumulation of microalgae Auxenochlorella protothecoides cultivated in concentrated municipal wastewater. Appl Biochem Biotechnol 166, 1661, 2012.

11. HUSSAIN F., SHAH S.Z., ZHOU W., IQBAL M. Microalgae screening under $\mathrm{CO}_{2}$ stress: Growth and micronutrients removal efficiency. Journal of Photochemistry and Photobiology B: Biology, 2017.
12. ATIKU H., MOHAMED R.M.S.R., AL-GHEETHI A.A., WUROCHEKKE A.A., KASSIM A.H.M. Harvesting of microalgae biomass from the phycoremediation process of greywater. Environmental Science and Pollution Research 23, 24624, 2016.

13. BAICHA Z., SALAR-GARCIA M.J., ORTIZ-MARTINEZ V.M., HERNANDEZ-FERNANDEZ F.J., DE LOS RIOS A.P., et al. A critical review on microalgae as an alternative source for bioenergy production: A promising low cost substrate for microbial fuel cells. Fuel Processing Technology 154, 104, 2016.

14. CHEN G., ZHAO L., QI Y. Enhancing the productivity of microalgae cultivated in wastewater toward biofuel production: A critical review. Applied Energy 137, 282, 2015.

15. DELRUE F., ALVAREZ-DIAZ P.D., FON-SING S., FLEURY G., SASSI J.-F. The Environmental Biorefinery: Using Microalgae to Remediate Wastewater, a Win-Win Paradigm. Energies 9, 2016.

16. GARCIA-GARCIA J.D., SANCHEZ-THOMAS R., MORENO-SANCHEZ R. Bio-recovery of non-essential heavy metals by intra- and extracellular mechanisms in free-living microorganisms. Biotechnology Advances 34, 859, 2016.

17. GERARDO M.L., VAN DEN HENDE S., VERVAEREN H., COWARD T., SKILL S.C. Harvesting of microalgae within a biorefinery approach: A review of the developments and case studies from pilot-plants. Algal Research-Biomass Biofuels and Bioproducts 11, 248, 2015.

18. HALLENBECK P.C., GROGGER M., MRAZ M., VEVERKA D. Solar biofuels production with microalgae. Applied Energy 179, 136, 2016.

19. WANG J., ZHOU W., YANG H., WANG F., RUAN R. Trophic mode conversion and nitrogen deprivation of microalgae for high ammonium removal from synthetic wastewater. Bioresource Technology 196, 668, 2015.

20. HE P.J., MAO B., SHEN C.M., SHAO L.M., LEE D.J., et al. Cultivation of Chlorella vulgaris on wastewater containing high levels of ammonia for biodiesel production. Bioresour Technol 129, 177, 2013.

21. HO L., HO G. Mitigating ammonia inhibition of thermophilic anaerobic treatment of digested piggery wastewater: use of $\mathrm{pH}$ reduction, zeolite, biomass and humic acid. Water Res 46, 4339, 2012.

22. ZIMMO O.R., VAN DER STEEN N.P., GIJZEN H.J. Comparison of ammonia volatilisation rates in algae and duckweed-based waste stabilisation ponds treating domestic wastewater. Water Res 37, 4587, 2003.

23. CAI T., PARK S.Y., LI Y. Nutrient recovery from wastewater streams by microalgae: Status and prospects. Renewable \& Sustainable Energy Reviews 19, 360, 2013.

24. ZHOU W., LI Y., MIN M., HU B., CHEN P., et al. Local bioprospecting for high-lipid producing microalgal strains to be grown on concentrated municipal wastewater for biofuel production. Bioresource Technology 102, 6909, 2011.

25. ZHOU W., CHEN P., MIN M., MA X., WANG J., et al. Environment-enhancing algal biofuel production using wastewaters. Renewable \& Sustainable Energy Reviews 36, 256, 2014.

26. ZHOU W., CHENG Y., LI Y., WAN Y., LIU Y., et al. Novel fungal pelletization-assisted technology for algae harvesting and wastewater treatment. Appl Biochem Biotechnol 167, 214, 2012.

27. ZHOU W., HU B., LI Y., MIN M., MOHR M., et al. Mass cultivation of microalgae on animal wastewater: 
a sequential two-stage cultivation process for energy crop and omega-3-rich animal feed production. Appl Biochem Biotechnol 168, 348, 2012.

28. SALAH-UD-DIN K., M.S, HUSSAIN F. Documentation of microalgal species from selected regions of Peshawarvalley, Khyber Pakhtunkhawa (KPK), Pakistan. Pure Appl Biol. 2017.

29. SHAH S.Z., FARIDI M. Some Green Algae from Paddy Fields of Mathra (DISTT: PESHAWAR);. Department of Botany, University of Peshawar. 239, 1982.

30. HOH D., WATSON S., KAN E. Algal biofilm reactors for integrated wastewater treatment and biofuel production: A review. Chemical Engineering Journal 287, 466, 2016.

31. HWANG J.-H., CHURCH J., LEE S.-J., PARK J., LEE W.H. Use of Microalgae for Advanced Wastewater Treatment and Sustainable Bioenergy Generation. Environmental Engineering Science 33, 882, 2016.

32. JUDD S., VAN DEN BROEKE L.J.P., SHURAIR M., KUTI Y., ZNAD H. Algal remediation of $\mathrm{CO}_{2}$ and nutrient discharges: A review. Water Research 87, 356, 2015.

33. KLIGERMAN D.C., BOUWER E.J. Prospects for biodiesel production from algae-based wastewater treatment in Brazil: A review. Renewable \& Sustainable Energy Reviews 52, 1834, 2015.

34. LIBRALATO G., PRATO E., MIGLIORE L., CICERO A.M., MANFRA L. A review of toxicity testing protocols and endpoints with Artemia spp. Ecological Indicators 69, 35, 2016.

35. MAITY J.P., BUNDSCHUH J., CHEN C.-Y., BHATTACHARYA P Microalgae for third generation biofuel production, mitigation of greenhouse gas emissions and wastewater treatment: Present and future perspectives - A mini review. Energy 78, 104, 2014.

36. ZHOU W., MIN M., HU B., MA X., LIU Y., Et al. Filamentous fungi assisted bio-flocculation: A novel alternative technique for harvesting heterotrophic and autotrophic microalgal cells. Separation and Purification Technology 107, 158, 2013.

37. DU Z., HU B., SHI A., MA X., CHENG Y., et al. Cultivation of a microalga Chlorella vulgaris using recycled aqueous phase nutrients from hydrothermal carbonization process. Bioresour Technol 126, 354, 2012.

38. DU Z., MA X., LI Y., CHEN P., LIU Y., Et al. Production of aromatic hydrocarbons by catalytic pyrolysis of microalgae with zeolites: catalyst screening in a pyroprobe. Bioresour Technol 139, 397, 2013.

39. HU B., MIN M., ZHOU W., DU Z., MOHR M., et al. Enhanced mixotrophic growth of microalga Chlorella sp. on pretreated swine manure for simultaneous biofuel feedstock production and nutrient removal. Bioresour Technol 126, 71, 2012.

40. MIN M., WANG L., LI Y., MOHR M.J., HU B., et al. Cultivating Chlorella sp. in a pilot-scale photobioreactor using centrate wastewater for microalgae biomass production and wastewater nutrient removal. Appl Biochem Biotechnol 165, 123, 2011.

41. KHATTAK T., BHATTI N.Z., MURTAZA G. Evaluation of algae from the effluent of Dandot Cement Company, Dandot, Pakistan, 2005.

42. SARIM F., KOUSER A. Some member of order Chloroccoccales of district Haripur. Pakistan Journal of Plant Sciences 13, 2007.

43. CHUGHTAI M.I., KAUSAR T., MAHMOOD K., NAEEM M., AWAN A.R. Studies on Limnological Characteristics and Planktonic Diversity in Dg Khan Canal Water At Dg Khan (Pakistan). Pakistan Journal of Botany 45, 599, 2013.

44. ALI A., SHINWARI Z.K., SARIM F.M. Contribution to the algal flora (Chlorophyta) of fresh waters of district Swat. NWFP, Pakistan. Pak J Bot 42, 3457, 2010.

45. SHER K., HAZRAT A. Taxonomic study of green algae of lower river Swat KPK, Pakistan. FUUAST Journal of Biology 2, 2012.

46. SARIM F., JEHAN M., NISA K. Genera Oedogonium and Bulbochaete (order Oedogoniales) of Peshawar valley, Pakistan. Pak J Pl Sci 15, 107, 2009.

47. ZARINA A., SHAMEEL M. Occurrence of the genus Bulbochaete (Zygnemophyceae Shameel) from Gujranwala and Lahore Districts of Pakistan. Proceedings-Pakistan Academy of Sciences 44, 105, 2007.

48. LEGHARI S.M., ARBANI S., JEHANGIR T. Chlorococcales (Chlorophyta) of Sindh, Pakistan, 2001.

49. KORAI A., SAHATO G., LASHARI K., ARBANI S. Biodiversity in relation to physico-chemical properties of Keenjhar lake, Thatta district, Sindh, Pakistan. Turkish Journal Fisheries and Aquatic Sciences 8, 259, 2008.

50. LEGHARI S. Some Fresh Water Green Filamentous Algae (Chlorophyta) and Dinoboron cilindrica (Chrysophyta) from Lakes and Riverin Ponds of Sindh, Pakistan. Pakistan Journal of Biological Sciences 1, 145, 2001.

51. HUSSAIN F., LEGHARI M., AHMAD H., IQBAL A., SALEEM M., et al. Taxonomic study of freshwater unicellular green algal species from Peshawar valley. International Journal of Phycology and Phycochemistry 7, 2011.

52. NAZNEEN S., BARI G. Seasonal distribution of phytoplankton in Haleji lake. Pakistan Journal of Agricultural Research 5, 183, 1984.

53. SHAHNAZ A., ZARINA A., SHAMEEL M. Survey of some volvocophyta Shameel from Lahore, Pakistan. International Journal of Phycology and Phycochemistry 3, 2007.

54. SARIM F.M. A Monograph on the Desmids of Pakistan: University of Peshawar, Peshawar, 1982.

55. KHAIR-UN-NISA F., KOUSER A. Some Member of Order Chloroccoccales of District Haripur. Pak J Pl Sci 135, 141, 2007.

56. IQBAL F., ALI M., KANWAL N. Limnological Study of River Soan (Punjab), Pakistan. Agriculturae Conspectus Scientificus (ACS) 71, 65, 2006.

57. LEGHARI M., WAHEED S.B., LEGHARI M. Ecological Study of Algal Flora of Kunhar River of Pakistan. Pakistan Journal of Botany 33, 176, 2001.

58. ZARINA A., SHAMEEL M. Taxonomic study on volvocophyceae Shameel from certain areas of the Punjab. Pakistan Journal of Botany 40, 2008.

59. SAMREEN U., HUSSAIN F., ALI N. Fresh water algae from River Naguman near Shakarpura, District Peshawar, Pakistan. Pakistan Journal of Plant Sciences 18, 2012.

60. ZAMAN A., SARIM F. Some freshwater algae found in various localities of Peshawar valley [Pakistan]. International Journal of Biology and Biotechnology 2, 2005.

61. BADSHAH L., HUSSAIN F., ALI N. Chlorophycean Algae of Kurram River, Parachinar, Pakistan. Pakistan Journal of Plant Sciences, 2011.

62. HUSNA R., ZARINA A., SHAMEEL M. Taxonomic study of volvocophyta Shameel from fountain water of 
Lahore, Pakistan. International Journal of Phycology and Phycochemistry 4, 2008.

63. JAVED M. Studies on metal contamination levels in plankton and their role as biological indicator of water pollution in the river Ravi. Pakistan J Biol Sci, 313, 2006.

64. HABIB I., CHATURVEDI U. Pediastrum-Habibii Sp-Nov, an Interesting New Alga. Pakistan Journal Of Botany 24, 213, 1992.

65. SALAH-UD-DIN K., SHUAIB M., HUSSAIN F. Documentation of microalgal species from selected regions of Peshawar valley, Khyber Pakhtunkhawa (KPK), Pakistan. Pure and Applied Biology, 2017.

66. BUTT G.Y. Investigations on Phycochemistry and Bioactivity of Eleven Freshwater Green Algae of Sindh: University of Karachi, Karachi. 2003.

67. AKHTAR N., REHMAN S.R. Some members of ulotrichales from Jalala, District Mardan, Pakistan. Pak J Pl Sci 15, 19, 2009.

68. SANTOS-BALLARDO D.U., ROSSI S., REYESMORENO C., VALDEZ-ORTIZ A. Microalgae potential as a biogas source: current status, restraints and future trends. Reviews in Environmental Science and BioTechnology 15, 243, 2016.

69. SCHNURR P.J., ALLEN D.G. Factors affecting algae biofilm growth and lipid production: A review. Renewable \& Sustainable Energy Reviews 52, 418, 2015.

70. SINGH V., TIWARI A., DAS M. Phyco-remediation of industrial waste-water and flue gases with algal-diesel engenderment from micro-algae: A review. Fuel 173, 90, 2016.

71. SOLOVCHENKO A., VERSCHOOR A.M., JABLONOWSKI N.D., NEDBAL L. Phosphorus from wastewater to crops: An alternative path involving microalgae. Biotechnology Advances 34, 550, 2016.

72. TARAYRE C., DE CLERCQ L., CHARLIER R., MICHELS E., MEERS E., et al. New perspectives for the design of sustainable bioprocesses for phosphorus recovery from waste. Bioresource Technology 206, 264, 2016.

73. UMAMAHESWARI J., SHANTHAKUMAR S. Efficacy of microalgae for industrial wastewater treatment: a review on operating conditions, treatment efficiency and biomass productivity. Reviews in Environmental Science and Bio-Technology 15, 265, 2016.

74. WAGNER D.S., VALVERDE-PEREZ B., SAEBO M., DE LA SOTILLA M.B., VAN WAGENEN J., et al. Towards a consensus-based biokinetic model for green microalgae - The ASM-A. Water Research 103, 485, 2016.

75. WANG S.-K., STILES A.R., GUO C., LIU C.-Z. Microalgae cultivation in photobioreactors: An overview of light characteristics. Engineering in Life Sciences 14, 550,2014

76. WARD A.J., LEWIS D.M., GREEN B. Anaerobic digestion of algae biomass: A review. Algal ResearchBiomass Biofuels and Bioproducts 5, 204, 2014.

77. ZENG X., GUO X., SU G., DANQUAH M.K., ZHANG S., et al. Bioprocess considerations for microalgal-based wastewater treatment and biomass production. Renewable \& Sustainable Energy Reviews 42, 1385, 2015.

78. CHO K., SHIN S.G., LEE J., KOO T., KIM W., et al. Nitrification resilience and community dynamics of ammonia-oxidizing bacteria with respect to ammonia loading shock in a nitrification reactor treating steel wastewater. J Biosci Bioeng 122, 196, 2016.
79. DOMINGOS S.S., DALLAS S., SKILLMAN L., FELSTEAD S., HO G. Nitrogen removal and ammoniaoxidising bacteria in a vertical flow constructed wetland treating inorganic wastewater. Water Sci Technol 64, 587, 2011.

80. KIM Y.M. Acclimatization of communities of ammonia oxidizing bacteria to seasonal changes in optimal conditions in a coke wastewater treatment plant. Bioresour Technol 147, 627, 2013.

81. LIAN Y., XU M., ZHONG Y., YANG Y., CHEN F., et al. Ammonia oxidizers in a pilot-scale multilayer rapid infiltration system for domestic wastewater treatment. PLoS One 9, el14723, 2014.

82. ADENAN N.S., YUSOFF F.M., MEDIPALLY S.R., SHARIFF M. Enhancement of lipid production in two marine microalgae under different levels of nitrogen and phosphorus deficiency. Journal of Environmental Biology 37, 669, 2016.

83. BROWN N., SHILTON A. Luxury uptake of phosphorus by microalgae in waste stabilisation ponds: current understanding and future direction. Reviews in Environmental Science and Bio-Technology 13, 321, 2014.

84. CHO S., KIM J., KIM S., LEE S.S. Nitrogen and phosphorus treatment of marine wastewater by a laboratory-scale sequencing batch reactor with ecofriendly marine high-efficiency sediment. Environ Technol: 1, 2017.

85. DE-BASHAN L.E., MORENO M., HERNANDEZ J.P., BASHAN Y. Removal of ammonium and phosphorus ions from synthetic wastewater by the microalgae Chlorella vulgaris coimmobilized in alginate beads with the microalgae growth-promoting bacterium Azospirillum brasilense. Water Res 36, 2941, 2002.

86. KONG Q.X., LI L., MARTINEZ B., CHEN P., RUAN R. Culture of microalgae Chlamydomonas reinhardtii in wastewater for biomass feedstock production. Appl Biochem Biotechnol 160, 9, 2010.

87. LI M., WAN C.-Y., PAN X.-J., ZOU Y., CHI S.-Y., et al. comparative study of stress by four heavy metals on chlamydomonas reinhardtii and the potential application in bbe algae toximeter. Fresenius Environmental Bulletin 22, 1494, 2013.

88. AHMED A., JYOTHI N., RAMESH A. Improved ammonium removal from industrial wastewater through systematic adaptation of wild type Chlorella pyrenoidosa. Water Science and Technology 75, 182, 2017.

89. CHENG J., YE Q., YANG Z., YANG W., ZHOU J., et al. Microstructure and antioxidative capacity of the microalgae mutant Chlorella PY-ZU1 during tilmicosin removal from wastewater under $15 \% \mathrm{CO}_{2}$. Journal of Hazardous Materials 324, 414, 2017.

90. DENG D., TAM N.FY. Adsorption-uptake-metabolism kinetic model on the removal of BDE-47 by a Chlorella isolate. Environmental Pollution 212, 290, 2016.

91. HE P.J., MAO B., LU F., SHAO L.M., LEE D.J., et al. The combined effect of bacteria and Chlorella vulgaris on the treatment of municipal wastewaters. Bioresource Technology 146, 562, 2013.

92. BAGLIERI A., SIDELLA S., BARONE V., FRAGALA F., SILKINA A., et al. Cultivating Chlorella vulgaris and Scenedesmus quadricauda microalgae to degrade inorganic compounds and pesticides in water. Environmental Science and Pollution Research 23, 18165, 2016 
93. LUTZU G.A., ZHANG W., LIU T. Feasibility of using brewery wastewater for biodiesel production and nutrient removal by Scenedesmus dimorphus. Environmental Technology 37, 1568, 2016.

94. PANCHA I., CHOKSHI K., MAURYA R., TRIVEDI K., PATIDAR S.K., et al. Salinity induced oxidative stress enhanced biofuel production potential of microalgae Scenedesmus sp. CCNM 1077. Bioresour Technol 189, 341, 2015.

95. ZHANG E., WANG B., WANG Q., ZHANG S., ZHAO B. Ammonia-nitrogen and orthophosphate removal by immobilized Scenedesmus sp. isolated from municipal wastewater for potential use in tertiary treatment. Bioresour Technol 99, 3787, 2008.

96. ZHANG T.-Y., HU H.-Y., WU Y.-H., ZHUANG L.-L., XU X.-Q., et al. Promising solutions to solve the bottlenecks in the large-scale cultivation of microalgae for biomass/ bioenergy production. Renewable \& Sustainable Energy Reviews 60, 1602, 2016.

97. ZHU L. Microalgal culture strategies for biofuel production: a review. Biofuels Bioproducts \& BiorefiningBiofpr 9, 801, 2015.

98. ZHUANG L.-L., WU Y.-H., ESPINOSA V.M.D., ZHANG T.-Y., DAO G.-H., et al. Soluble Algal Products (SAPs) in large scale cultivation of microalgae for biomass/bioenergy production: A review. Renewable \& Sustainable Energy Reviews 59, 141, 2016.

99. CHANDRA R., SUBHASH G.V., MOHAN S.V. Mixotrophic operation of photo-bioelectrocatalytic fuel cell under anoxygenic microenvironment enhances the light dependent bioelectrogenic activity. Bioresource Technology 109, 46, 2012.

100. COATS E.R., BRINKMAN C.K., LEE S. Characterizing and contrasting the microbial ecology of laboratory and full-scale EBPR systems cultured on synthetic and real wastewaters. Water Research 108, 124, 2017.
101. DE GODOS I., GUZMAN H.O., SOTO R., GARCIAENCINA P.A., BECARES E., et al. Coagulation/ flocculation-based removal of algal-bacterial biomass from piggery wastewater treatment. Bioresource Technology 102, 923, 2011.

102. MAKAREVICIENE V., SKORUPSKAITE V., ANDRULEVICIUTE V. Biodiesel fuel from microalgaepromising alternative fuel for the future: a review. Reviews in Environmental Science and Bio-Technology 12, 119, 2013.

103. MONTEMEZZANI V., DUGGAN I.C., HOGG I.D., CRAGGS R.J. A review of potential methods for zooplankton control in wastewater treatment High Rate Algal Ponds and algal production raceways. Algal Research-Biomass Biofuels and Bioproducts 11, 211, 2015.

104. PAWAR S. Effectiveness mapping of open raceway pond and tubular photobioreactors for sustainable production of microalgae biofuel. Renewable \& Sustainable Energy Reviews 62, 640, 2016.

105. RANGABHASHIYAM S., SUGANYA E., SELVARAJU N., VARGHESE L.A. Significance of exploiting nonliving biomaterials for the biosorption of wastewater pollutants. World Journal of Microbiology \& Biotechnology 30, 1669, 2014.

106. RAZZAK S.A., HOSSAIN M.M., LUCKY R.A., BASSI A.S., DE LASA H. Integrated $\mathrm{CO}_{2}$ capture, wastewater treatment and biofuel production by microalgae culturing-A review. Renewable \& Sustainable Energy Reviews 27, 622, 2013.

107. RENUKA N., SOOD A., PRASANNA R., AHLUWALIA A.S. Phycoremediation of wastewaters: a synergistic approach using microalgae for bioremediation and biomass generation. International Journal of Environmental Science and Technology 12, 1443, 2015. 
